\title{
Morphological Characters and Yield Performance of Six Accessions of Sri Lankan Traditional Rice Variety "Mudukiri Al"
}

\author{
D. Padukkage ${ }^{1}$ and S. Geekiyanage ${ }^{2 *}$
}

\begin{abstract}
Sri Lankan traditional rice germplasm consists of varieties with a wide variation in morphology. One rice variety is comprised of many accessions. Determination of morphological variation and yield potential among accessions within the same variety would be useful for breeding new varieties and farmer introductions. Six accessions of Mudukiri Al, a short aged and red grained traditional rice variety were grown in completely randomized design and tested for nineteen morphological and yield traits including days to flowering (DF), plant height at flowering (PH), leaf area (LA), culm number $(\mathrm{CN})$, total number of panicles (FT), number of secondary branches per panicle (NSB), number of spikelets per first panicle (NSP), grain length (GL) and grain width (GW) that showed significant differences among accessions. Four principal components resulted from Principal Component analysis accounted for $\mathbf{9 5 . 7 1 6 \%}$ of the total variation. The accession 4144 having significantly higher LA $\left(44.4 \mathrm{~cm}^{2} \pm\right.$ 2.158), CN (38 \pm 7.25$)$, NSP $(255 \pm 15.34)$ and NSB $(28 \pm 4.58)$ was individually clustered, which could be a candidate in future breeding programmes. Significant relationships between quantitative vegetative and yield characters were observed. Delayed flowering time increased the vegetative growth and reduced the grain size suggesting
\end{abstract}

\footnotetext{
${ }^{1}$ Board of Study in Agriculture, Faculty of Graduate Studies, University of Ruhuna, Matara, Sri Lanka

${ }^{2}$ Department of Agricultural Biology, Faculty of Agriculture, University of Ruhuna, Mapalana, Kamburupitiya, Sri Lanka *sudarshanee@agbio.ruh.ac.lk
}

a common relationship model between the DF and vegetative and yield components among the tested accessions.

Keywords: Breeding Resource, Morphological Variation, Mudukiri Al, Traditional rice variety

\section{INTRODUCTION}

Being the staple food with a per-capita consumption of $114 \mathrm{~kg}$ per year, rice plays a major role in nutritional status of the people of Sri Lanka (Rebeira et al., 2014). Due to the remarkable rice production, Sri Lanka has reached the self-sufficiency in rice with an average rice production of 3.6 million metric tons per year (FAO, 2014). More than 1.8 million farmers depend on rice cultivation wherein about $30 \%$ of the total labour force in Sri Lanka directly or indirectly involved in rice sector (FAO, 2014).

Bambaradeniya and Amerasinghe (2004) reported that unfavorable climatic and environmental conditions and reduction of land use could adversely affect the rice production in the near future. Therefore, it is necessary to increase the rice production by enhancing its genetic diversity through breeding new varieties to face future challenges of climate change (Yoshida, 1983). 
The germplasm of traditional rice of Sri Lanka is composed of more than 500 rice varieties, most of which have not yet been characterized for their favorable morphological traits of agronomic importance. Identification of high yielding rice varieties, along with the adaptive performances under biotic and abiotic stresses would be important to employ them in future breeding programmes. From the ancient times traditional rice varieties played an important role in Sri Lankan Agriculture. With the British invasion, more emphasis was given to plantation crops neglecting the rice cultivation. Later, Department of Agriculture introduced improved high yielding rice varieties during the green revolution replacing the traditional rice varieties. Improved varieties are short in height, comparatively high tillering, high yielding and highly responsive to chemical fertilizers (IRRI, 2009). Plant Genetic Resource Centre (PGRC) of Sri Lanka conserves traditional rice in the gene bank for future needs.

Meanwhile, the awareness on harmful effects of chemical fertilizer and pesticides, which were not used for traditional rice in the past and benefits of traditonal rice such as composition of higher amounts of glutamic acid, vitamins and fiber, and lower glycemic index, led to the current trend towards reintroduction of traditional rice (Berger, 2009; Dharmasena, 2010). There are several key challenges when promoting traditional rice in Sri Lanka. Currently, Sri Lankan traditional rice cultivation is limited only to $0.1 \%$ of the total rice cultivated area (Wang et al., 2012). Furthermore, farmers lack the knowledge on short term traditional rice varieties, which give higher yield. Short aged rice varieties would be a solution for increasing demand for food by increasing population further. The information on superior early flowering rice genotypes is a current requirement to be conveyed to breeders to address the future climate change and increasing population needs.

Six accessions of Sri Lankan traditional rice variety, "Mudukiri Al" were used for this experiment. Mudukiri Al is a short aged red rice variety, grown in wet zone of Sri Lanka. It is known that Mudukiri $A l$ rice is used for improvement of immunity in ayurvedic medicine. The objective of this study was to determine the diversity of six Mudukiri Al accessions obtained from Plant Genetic Resources Centre (PGRC), Gannoruwa, Sri Lanka based on selected morphological traits and to select better performing Mudukiri Al accessions to be used in future breeding programmes.

\section{MATERIALS AND METHODS}

\section{Selected Rice Accessions, Seed Germination and Field Establishment}

Seeds of six accessions of Mudukiri Al (MK3591, MK3738, MK3970, MK4144, MK4145 and MK5536) were obtained from PGRC, Gannoruwa, Sri Lanka. Seeds of each accession were soaked in water overnight in labeled cups and then placed in mud pots. Seedlings were maintained in pots for 2 to 3 weeks until field establishment. Uniform healthy seedlings were selected for transplanting in the field. The experiment was conducted in a farmer 
field ( $6^{\circ} 17^{\prime} 0^{\prime \prime}$ North, 81 17' 0" East, $24 \mathrm{~m}$ above mean sea level) situated at Kamburupitiya, Sri Lanka (in agro ecological zone IL1) in wet season with North Eastern monsoon rains (Maha season of short day photoperiodic condition) from October 2013 to January 2014. Temperature ranged from $28.3{ }^{\circ} \mathrm{C}$ to $31.7^{\circ} \mathrm{C}$ and relative humidity from $67 \%$ to $97 \%$ that were measured using a weather station (YSE975-600B, Fisher Scientific UK) during the cultivation period. The duration of sun shine hours varied from 11.52 hours to 12.31 hours during cultivation season.

When fertilizing the field, only the basal dressing was added according to the recommendations of the Department of Agriculture, Sri Lanka (Urea $50 \mathrm{~kg} / \mathrm{ha}$, TSP $62.5 \mathrm{~kg} / \mathrm{ha}$ and MOP $50 \mathrm{~kg} / \mathrm{ha}$ ). Fertilizer recommendation for newly improved varieties was followed for traditional rice accessions, as there were no special recommendations developed for traditional varieties. Manual weeding was done to avoid harmful effects to the plants by using weedicides. Approximately permanent standing water level of $5 \mathrm{~cm}$ was maintained throughout the experiment. Pest and disease management and weed control were practiced as a combination of both indigenous methods (light traps, manual weeding and sounders) and recommendations of Department of Agriculture.

\section{Experimental Design and Data Collection}

Field experiment was established according to the Completely Randomized Design (CRD) with 4 replicates. Plants were grown in rows with the spacing of $20 \mathrm{~cm} \times 20 \mathrm{~cm}$ within and between rows. Data was collected in three growth stages according to the guidelines of Standard Evaluation System for Rice (PGRC, 2006); fifth leaf stage (vegetative stage), flowering stage (reproductive stage) and maturity stage. The measured characters in each stage and the method of measurement are given in the Table 1. The leaf temperature difference was calculated by subtracting the temperature of flag leaf measured by the Leaf Temperature meter (Specturm technologies. Inc., Australia) and the prevailing environmental temperature in field.

\section{Statistical Analysis}

Descriptive statistics were used for variation of selected agro-morphological traits. Analysis of variance (ANOVA) was performed using SPSS software (version.20, USA) for significant differences among accessions. Principal Component Analysis (PCA) and Hierarchal Cluster Analysis (HCA) were conducted using quantitative agro-morphological traits of rice accessions through SPSS to analyze the diversity of accessions. A dendrogram was constructed through Ward Linkage method to depict the genetic diversity of the accessions. Correlation analysis was carried out for relationships between the measured traits. Duncan Multiple Range Test (DMRT) based mean separation was carried to determine the accessions with significant values for selected traits using SAS. 
Table 1: Plant traits measured and their abbreviations

\begin{tabular}{|c|c|c|}
\hline Growth stage & Trait & Units \\
\hline \multirow{5}{*}{ Fifth leaf stage } & Days to fifth leaf (DFL) & Days \\
\hline & Seedling height $(\mathrm{SH})$ & $\mathrm{cm}$ \\
\hline & Leaf temperature difference (TD) & ${ }^{0} \mathrm{C}$ \\
\hline & Culm number $(\mathrm{CNF})$ & Plant $^{-1}$ \\
\hline & Leaf area (LA) & $\mathrm{cm}^{2}$ \\
\hline \multirow{6}{*}{ Flowering stage } & Days to flowering (DF) & Days \\
\hline & Plant height (PH) & $\mathrm{cm}$ \\
\hline & Leaf number (LN) & Plant $^{-1}$ \\
\hline & Flag leaf length (FLL) & $\mathrm{cm}$ \\
\hline & Flag leaf width (FLW) & $\mathrm{cm}$ \\
\hline & Flag leaf angle (FLA) & Degrees \\
\hline \multirow{9}{*}{ Yield traits } & Culm number (CN) & Plant $^{-1}$ \\
\hline & Culm angle (CA) & Degrees \\
\hline & Culm diameter (CD) & $\mathrm{mm}$ \\
\hline & Number of secondary branches (NSB) & First panicle $^{-1}$ \\
\hline & First panicle length (FPL) & $\mathrm{cm}$ \\
\hline & Grain length (GL) & $\mathrm{cm}$ \\
\hline & Grain weight (GW) & $\mathrm{g}$ \\
\hline & Number of fertile tillers/plant (FT) & Plant $^{-1}$ \\
\hline & Number of spikelets/ $1^{1 \text { tspanicle (NSP) }}$ & First panicle ${ }^{-1}$ \\
\hline
\end{tabular}

\section{RESULTS AND DISCUSSION}

Analysis of Variance and Means of Morphological and Yield Traits

ANOVA and related statistics for selected 12 agro-morphological traits of 6 rice accessions are presented in the Table 2. Variations of the selected traits were observed. According to ANOVA each agromorphological trait was significantly different $(p<0.05)$ indicating the existence of the variation among the accessions within this variety. Sri Lankan traditional rice is known to be with wider variation in morphology and yield (Team of NRC 12129 Research Project, 2014). Previous studies have also determined this wider variation of days to flowering including photoperiod sensitivity (Chandraratne,
1964). In vegetative stage from $51 \pm 1.22$ to $59 \pm 0.994$ days of variation was observed at fifth leaf, while days to flowering varied from $86 \pm 0.847$ to $102 \pm 1.47$ days. Plant height at flowering stage ranged from 112.7 $\pm 2.31-148.6 \pm 1.89 \mathrm{~cm}$. Number of spikelets per first panicle ranged from 103 \pm 4.55 to $255 \pm 5.69$.

Above results indicate that all genotypes showed significant differences from each other $(p<0.001)$. The mean performance of the morphological traits revealed that the MK4144 was the earliest flowering Mudukiri Al accession. MK3970, MK3591 and MK4145 were the most delayed flowering accessions. MK3970 possessed the highest plant height while MK5536 was the shortest accession. The 
highest number of spikelets per first panicle and secondary branches per panicle were recorded from MK4144, whereas the lowest were from MK5536 and MK3591. MK4144 and MK3970 had the highest number of fertile tillers per plant while MK4145 was found with the lowest number of fertile tillers. In grain morphology, MK3970 possessed the shortest grain length and widest grain width, whereas MK4144 and MK5536 were observed with longest seed length.

\section{Principal Component Analysis (PCA)}

Principal Component Analysis resulted with four principal components (PCs) where Eigen value depicted in the scree plot is greater than 1, which accounted for $95.716 \%$ of the total variation (Figure 1). The vegetative agro-morphological traits that contributed positively to each Principal component (PC) and the percentages of variation are given in the Table 3 .

Among four PCs, PC1 consisted of both vegetative traits and yield traits. Majority of the agronomic traits (days to flowering, plant height, days to fifth leaf, culm number at fifth leaf stage, flag leaf length, flag leaf angle and culm diameter) and physiological trait of leaf temperature difference was included in $\mathrm{PC} 1$, which explained $40.153 \%$ of the total variation. Mainly yield components (number of spikelets per first panicle, fertile tiller number, number of secondary branches per panicle, first panicle length, leaf area and culm number) were included in PC2. The combination of the PC1 and PC2 explained $79 \%$ of the total variation. The $38.6 \%$,
$10.14 \%$ and $6.82 \%$ of variations were observed in $2^{\text {nd }}, 3^{\text {rd }}$ and $4^{\text {th }}$ PCs respectively. Flag leaf width and culm angle were included in PC3 while seedling height was included in PC4. 
Table 2: Variation of selected morphological characters during fifth leaf stage, flowering stage and grain maturity stage in $M u d u k i r i$ Al rice accessions.

\begin{tabular}{|c|c|c|c|c|c|c|c|c|c|c|c|c|}
\hline $\begin{array}{l}\text { Accession } \\
\text { number }\end{array}$ & $\begin{array}{c}\text { DFL } \\
\text { (days) }\end{array}$ & $\begin{array}{l}\mathrm{SH} \\
(\mathrm{cm})\end{array}$ & $\begin{array}{l}\text { TD } \\
\left({ }^{0} \mathrm{C}\right)\end{array}$ & $\begin{array}{c}\text { LA } \\
\left(\mathrm{cm}^{2}\right)\end{array}$ & $\begin{array}{c}\text { DF } \\
\text { (days) }\end{array}$ & $\begin{array}{l}\mathrm{PH} \\
(\mathrm{cm})\end{array}$ & $\begin{array}{c}\text { FT } \\
\text { (No.) }\end{array}$ & $\begin{array}{l}\text { FPL } \\
(\mathrm{cm})\end{array}$ & $\begin{array}{l}\text { NSP } \\
\text { (No.) }\end{array}$ & $\begin{array}{l}\text { NSB } \\
\text { (No.) }\end{array}$ & $\begin{array}{c}\mathrm{GL} \\
(\mathrm{cm})\end{array}$ & $\begin{array}{l}\mathrm{GW} \\
(\mathrm{cm})\end{array}$ \\
\hline MK3591 & 59 (a) & 63.8 (c) & 7 (a) & $15.46(\mathrm{~d})$ & 100 (a) & 130.7 (b) & $16(\mathrm{~b})$ & $25(\mathrm{c})$ & $103(d)$ & $16(d)$ & $0.8(\mathrm{~b})$ & $0.3(\mathrm{~b})$ \\
\hline MK3738 & 57 (b) & 76.5 (a) & 7 (a) & 32.69 (b) & 90 (b) & $128.5(b)$ & 19 (b) & 28 (a) & $166(\mathrm{c})$ & 25 (b) & $0.8(b)$ & $0.3(b)$ \\
\hline MK3970 & $56(b)$ & 78 (a) & 7 (a) & $32.21(b)$ & 102 (a) & 148.6 (a) & 29 (a) & 29 (a) & $184(b)$ & 28 (a) & $0.7(\mathrm{c})$ & $0.4(\mathrm{a})$ \\
\hline MK4144 & $56(b)$ & 80 (a) & $6(b)$ & 44.35 (a) & 86 (c) & 126.7 (b) & 26 (a) & 29 (a) & 255 (a) & 28 (a) & 0.9 (a) & $0.3(b)$ \\
\hline MK4145 & 57 (b) & 73 (b) & 7 (a) & $6.53(d)$ & 95 (a) & $132.3(b)$ & 7 (c) & $26(b)$ & $160(\mathrm{c})$ & $18(\mathrm{c})$ & $0.8(b)$ & $0.3(b)$ \\
\hline MK5536 & $51(\mathrm{c})$ & 68.7 (c) & $6(b)$ & $24.57(\mathrm{c})$ & 89 (b) & $112.7(\mathrm{c})$ & $18(b)$ & 27 (a) & $115(d)$ & $16(d)$ & 0.9 (a) & $0.3(b)$ \\
\hline Grand Mean & 56 & 74 & 6 & 26 & 94 & 130 & 19 & 27 & 164 & 22 & 1 & 0.3 \\
\hline Error & 1.02 & 4.83 & 0.62 & 4 & 3.27 & 2.67 & 4.71 & 0.59 & 5.83 & 1.79 & 0.02 & 0.01 \\
\hline $\begin{array}{l}\text { Standard } \\
\text { deviation }\end{array}$ & 2.31 & 5.79 & 0.41 & 12.33 & 5.85 & 10.54 & 7.05 & 1.64 & 49.77 & 5.11 & 0.07 & 0.04 \\
\hline $\begin{array}{l}\text { Sums of } \\
\text { squares }\end{array}$ & 18857 & 32768.1 & 252.3 & 4958.38 & 52861.84 & 101925.7 & 2438.78 & 4399.1 & 175394.5 & 2973.50 & 4.03 & 0.61 \\
\hline CV \% & 4.1 & 7.9 & 6.4 & 47.5 & 6.2 & 8.1 & 37.3 & 6.1 & 30.4 & 23.6 & 8.4 & 11.8 \\
\hline
\end{tabular}

Note: DFL: Days to fifth leaf, SH: Seedling height, TD: Leaf temperature difference, LA: Leaf area, DF: Days to flowering, PH: Plant height, FT: Fertile tiller number, FPL: First panicle length, NSP: Number of spikelets / $1^{\text {st }}$ panicle, NSB: Number of secondary branches, GL: Grain length, GW: Grain weight. Means followed by same letter within a column are not significantly different at 0.05 significance level. 
Table 3: Principal components, percentage of variances and variables belonging to each Principal component (PC)

\begin{tabular}{ccc}
\hline PC & $\begin{array}{c}\text { \% of } \\
\text { variance }\end{array}$ & Variables belonging for each PC \\
1 & 40.153 & DFL, CNFL, DF, PH, TD, FLL, FLA, CD, NSB, GW \\
2 & 38.6 & CN, LA, FPL, NSP, FT, GL \\
3 & 10.139 & FLW, CA \\
4 & 6.825 & SH \\
\hline Total & 95.716 & \\
Variance & & \\
\hline
\end{tabular}

Note: DFL: Days to fifth leaf, TD: Leaf temperature difference, SH: Seedling height, CNFL: Culm number at fifth leaf stage, LA: Leaf area, DF: Days to flowering, PH: Plant height, FLL: Flag leaf length, FLW: Flag leaf width, FLA: Flag leaf angle, CN: Culm number, CA: Culm angle, CD: Culm diameter, FPL: First panicle length, NSB: Number of secondary branches, GL: Grain length, GW: Grain width, FT: Number of fertile tillers/plant, NSP: Number of spikelets/1 ${ }^{\text {st }}$ panicle

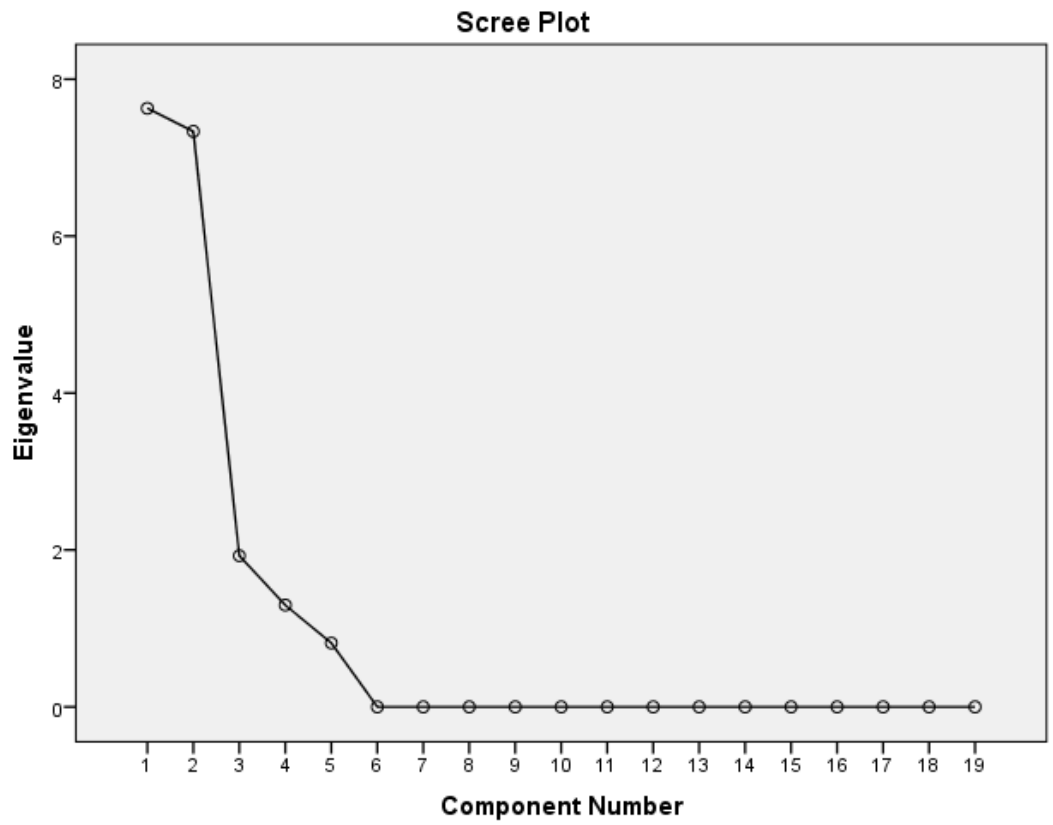

Figure 1: Scree plot resulted in Principal Component Analysis 


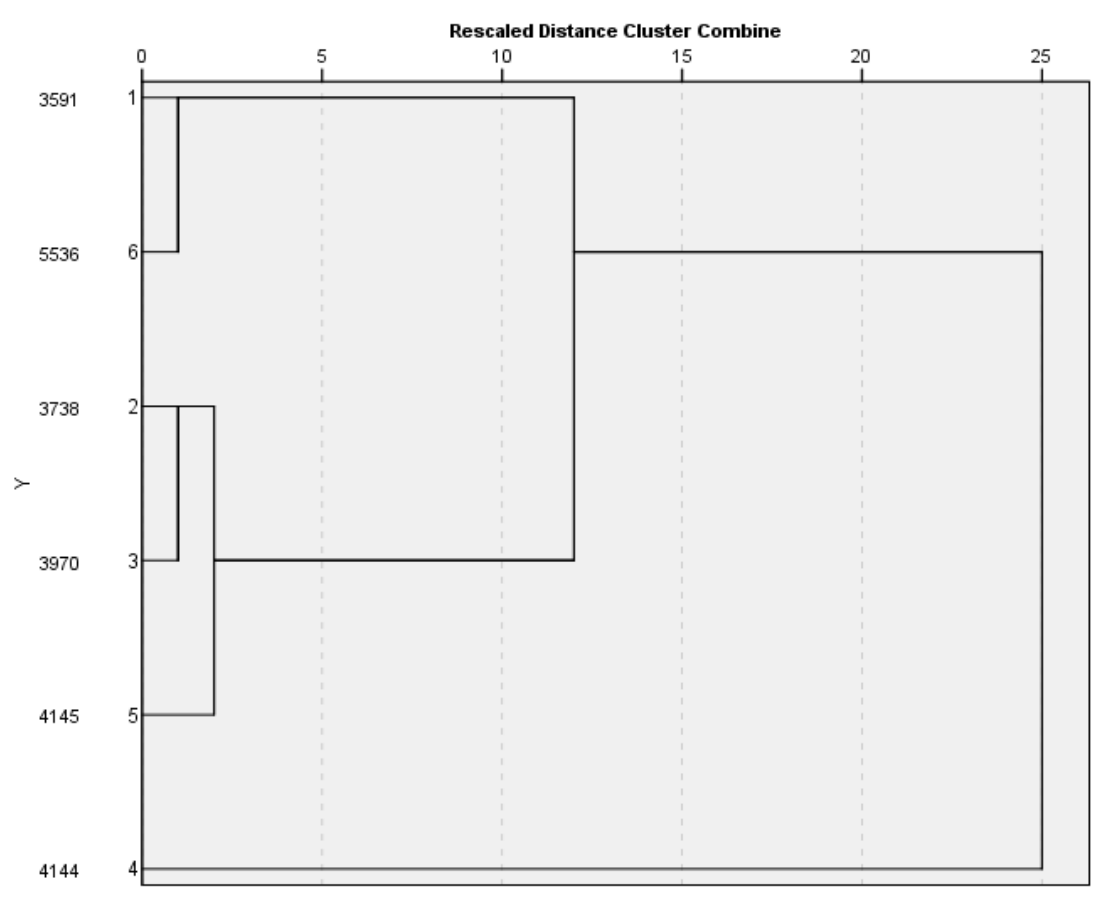

Figure 2: The dendrogram using Ward Linkage for genetic diversity depicted through morphological and physiological variation during three stages of growth recorded in six rice accessions of Mudukiri Al variety.

\section{Hierarchal Cluster Analysis (HCA)}

Three main clusters were observed at the rescaled distance of 5, which further divided into four sub-clusters at the rescaled distance between 0 and 3 (Figure 2). Accessions 3591 and 5536 belonging to main cluster 1 , gave the lowest values for seedling height, number of spikelets per first panicle and number of secondary branches (Table 4). MK4144 was individually clustered, which had significantly better performances: Higher seedling height $(80.3 \pm 0.125 \mathrm{~cm})$, leaf area $\left(44.4 \pm 2.158 \mathrm{~cm}^{2}\right)$, culm number $(38 \pm$ 7.25 ), number of spikelets per first panicle
$(255 \pm 15.34)$ and number of secondary branches $(28 \pm 4.58)$. Other three accessions (MK3738, MK3970 and MK4145) were included in a separate cluster. Accession MK4144 could be identified as a unique accession, which can be used in future breeding programmes and that can be nominated as a representative accession for the variety Mudukiri Al. Initial identification of distinguishable Sri Lankan traditional rice varieties by morphological characterization could be important to assess the molecular genetic background and its diversity for future breeding programmes. 
Table 4: Variation of quantitative characters of accessions of Mudukiri Al variety within clusters derived through Ward's linkage

\begin{tabular}{|c|c|c|c|c|c|c|c|c|c|c|c|c|c|c|c|c|c|c|c|c|c|}
\hline \multirow{2}{*}{$\begin{array}{c}\text { Cluster } \\
\text { number at } \\
\text { rescaled } \\
\text { distance of } \\
5\end{array}$} & \multirow[b]{2}{*}{$\begin{array}{c}\text { Accession } \\
\text { number }\end{array}$} & \multicolumn{5}{|c|}{ Vegetative stage } & \multicolumn{9}{|c|}{ Reproductive stage } & \multicolumn{6}{|c|}{ Maturity stage } \\
\hline & & DFL & $\mathrm{SH}$ & $\mathrm{TD}$ & LA & CNFL & $\mathrm{DF}$ & $\mathrm{PH}$ & $\mathrm{CN}$ & $\mathrm{CA}$ & $\mathrm{CD}$ & $\mathrm{LN}$ & FLL & FLW & FLA & FT & FPL & NSP & NSB & GL & GW \\
\hline \multirow{2}{*}{ Cluster 1} & MK3591 & 59 & 63.8 & 7 & 15.5 & 5 & 100 & 130.7 & 28 & 3 & 0.6 & 8 & 43.3 & 1.4 & 3 & 16 & 25 & 103 & 16 & 0.8 & 0.3 \\
\hline & MK5536 & 51 & 68.7 & 6 & 24.6 & 5 & 89 & 112.7 & 25 & 5 & 0.5 & 8 & 39.3 & 1.5 & 1 & 18 & 27 & 115 & 16 & 0.9 & 0.3 \\
\hline \multirow{3}{*}{ Cluster 2} & MK3738 & 57 & 76.5 & 7 & 32.7 & 3 & 90 & 128.5 & 31 & 3 & 0.5 & 8 & 44.0 & 1.3 & 3 & 19 & 28 & 166 & 25 & 0.8 & 0.3 \\
\hline & MK3970 & 56 & 78.9 & 7 & 32.2 & 10 & 102 & 148.6 & 33 & 1 & 0.6 & 8 & 46.0 & 1.5 & 3 & 29 & 29 & 184 & 27 & 0.7 & 0.4 \\
\hline & MK4145 & 57 & 73.8 & 7 & 6.5 & 4 & 95 & 132.3 & 16 & 3 & 0.6 & 8 & 39.7 & 1.6 & 3 & 7 & 26 & 160 & 18 & 0.8 & 0.3 \\
\hline Cluster 3 & MK4144 & 56 & 80.3 & 6 & 44.4 & 7 & 86 & 126.7 & 38 & 3 & 0.5 & 8 & 39.2 & 1.2 & 1 & 26 & 29 & 255 & 28 & 0.9 & 0.3 \\
\hline
\end{tabular}

method

Note: DFL: Days to fifth leaf, SH: Seedling height, TD: Leaf temperature difference, LA: Leaf area, CNFL: Culm number at fifth leaf stage, DF: Days to flowering, PH: Plant height, CN: Culm number, CA: Culm angle, CD: Culm diameter, LN: Leaf number, FLL: Flag leaf length, FLW: Flag leaf width, FLA: Flag leaf angle, FT: Number of fertile tillers/plant, FPL: First panicle length, NSP: Number of spikelets/1 ${ }^{\text {st }}$ panicle, NSB: Number of secondary branches, GL: Grain length, GW: Grain width 


\section{Correlation Analysis}

Correlations among the quantitative characters (significantly different at $\mathrm{p}<0.1$, 0.05 and 0.01 ) within variety Mudukiri Al are given in the Table 5. Days to fifth leaf significantly positively correlated with leaf temperature difference $(\mathrm{p}=0.037 ; \mathrm{r}=$ 0.722) while days to flowering correlated with culm diameter $(\mathrm{p}=0.013 ; \mathrm{r}=0.912)$. Grain length was observed with significantly negative relationships with days to flowering $(\mathrm{r}=-0.857)$, plant height $(r=-0.902)$, flag leaf length $(r=-0.863)$ and flag leaf angle $(r=-0.857)$ in which $p$ values were resulted as $0.034,0.014,0.028$ and 0.029 respectively. Significant positive relationships were observed between grain length and culm angle ( $p=0.036 ; r=0.84)$. According to Chandrarathna (1964), number of secondary branches per first panicle is a prominent yield determinant. Number of secondary branches showed a strong positive relationship with seedling height $(\mathrm{p}=0.011)$, first panicle length $(\mathrm{p}=$ 0.008 ) and number of spikelets per first panicle $(\mathrm{p}=0.033)$.

\section{There were positive}

relationships between days to flowering and vegetative growth characters i.e. plant height, culm diameter and flag leaf angle at the probability level of $\mathrm{p} \leq 0.1$.

Recent studies on molecular basis of flowering time in rice have suggested the mechanism of regulation of yield potential, plant height and flowering time (Wei et al., 2010). A significant relationship between plant height and flowering time had been reported (Lin et al., 2010). The flowering time genes, $H d l$, $E h d l$ and $G d h 7$ control the yield parameters in rice independently of DF (Endo-Higashi and Izawa, 2011). Yano (2001) emphasized on exploitation of naturally occurring variation for functional analysis of genes underlying complex traits. This emphasizes the need of molecular analysis for further implementation of these Sri Lankan rice accessions in future breeding programmes.

\section{CONCLUSION}

Accession MK4144 was identified as a potential representative accession of Mudukiri Al variety for further studies of the variety. Higher leaf area (44.4 \pm 2.158 $\mathrm{cm} 2)$, culm number $(38 \pm 7.25)$, number of spikelets per first panicle $(255 \pm 15.34)$ and number of secondary branches $(28 \pm 4.58)$ of MK4144, were considered when choosing this accession as a unique and representative accession of this variety. Furthermore, the study revealed that delayed flowering time increased the vegetative growth and reduced the grain size suggesting a common relationship model between DF and vegetative and yield components among traditional varieties. 
Table 5: Correlations among the quantitative characters within variety Mudukiri Al

\begin{tabular}{|c|c|c|c|c|c|c|c|c|c|c|c|c|c|c|c|c|c|c|c|}
\hline & & DFL & $\mathrm{SH}$ & TD & LA & CNFL & $\mathrm{DF}$ & $\mathrm{PH}$ & $\mathrm{CN}$ & $\mathrm{CA}$ & $\mathrm{CD}$ & FLL & FLW & FLA & FT & FPL & NSP & NSB & GL \\
\hline $\mathrm{SH}$ & $\mathrm{r}$ & -0.021 & 1 & & & & & & & & & & & & & & & & \\
\hline $\mathrm{TD}$ & $r$ & $.722^{*}$ & -0.102 & 1 & & & & & & & & & & & & & & & \\
\hline LA & $\mathrm{r}$ & -0.206 & .656 & -.488 & 1 & & & & & & & & & & & & & & \\
\hline CNFL & $\mathrm{r}$ & -0.089 & .423 & -0.103 & .437 & 1 & & & & & & & & & & & & & \\
\hline $\mathrm{DF}$ & $\mathrm{r}$ & .465 & -0.279 & .745 & -.461 & .403 & 1 & & & & & & & & & & & & \\
\hline $\mathrm{PH}$ & $r$ & .578 & .412 & .687 & 0.021 & .606 & $.742^{*}$ & 1 & & & & & & & & & & & \\
\hline $\mathrm{CN}$ & $\mathrm{r}$ & 0.059 & .477 & -.308 & $.926^{* * *}$ & .518 & -0.198 & 0.184 & 1 & & & & & & & & & & \\
\hline $\mathrm{CA}$ & $\mathrm{r}$ & -.589 & -.508 & -.612 & -0.178 & -.632 & -.642 & $-.985^{* * *}$ & -.335 & 1 & & & & & & & & & \\
\hline $\mathrm{CD}$ & $\mathrm{r}$ & .544 & -0.259 & .707 & -.641 & 0.292 & $.912^{* *}$ & $.692^{*}$ & -.411 & -.577 & 1 & & & & & & & & \\
\hline FLL & $\mathrm{r}$ & .439 & 0.09 & .712 & 0.11 & .359 & .702 & $.735^{*}$ & .310 & -.730 & $.409^{* * *}$ & 1 & & & & & & & \\
\hline FLW & $\mathrm{r}$ & -0.203 & -.333 & .351 & $-.781^{*}$ & 0.018 & .537 & 0.166 & $-.818^{* *}$ & 0 & .620 & 0.018 & 1 & & & & & & \\
\hline FLA & $\mathrm{r}$ & .722 & -0.102 & $1.000^{*}$ & -.488 & -0.103 & $.745^{*}$ & .687 & -.308 & -.612 & .707 & .712 & .351 & 1 & & & & & \\
\hline FT & $\mathrm{r}$ & -0.153 & .533 & -0.282 & $.870^{* * *}$ & $.773^{*}$ & -0.003 & .336 & $.906^{* *}$ & -.447 & -0.258 & .415 & -.509 & -0.282 & 1 & & & & \\
\hline FPL & $\mathrm{r}$ & -0.274 & $.891^{* *}$ & -.316 & $.873^{* *}$ & .571 & -.312 & 0.272 & .713 & -.387 & -.447 & 0.18 & -.444 & -.316 & $.813^{* *}$ & 1 & & & \\
\hline NSP & $\mathrm{r}$ & 0.082 & $.902^{* *}$ & -.301 & .706 & .415 & -.402 & 0.276 & .589 & -.401 & -0.298 & -0.138 & -.551 & -.301 & $.527^{*}$ & $.788^{*}$ & 1 & & \\
\hline NSB & $r$ & 0.141 & $.912^{* *}$ & -0.022 & $.807^{*}$ & .559 & -0.12 & .530 & .754 & -.653 & -0.22 & .364 & -.534 & -0.022 & $.770^{*}$ & $.913^{* *}$ & $.852^{* *}$ & 1 & \\
\hline GL & $\mathrm{r}$ & -.495 & -0.149 & -.857 & 0.213 & -.389 & $-.857^{* *}$ & $-.902^{* *}$ & 0.053 & $.840^{* *}$ & -.728 & $-.863^{* *}$ & -.391 & $-857^{* *}$ & -0.142 & -0.054 & 0.108 & -0.267 & 1 \\
\hline $\mathrm{GW}$ & $\mathrm{r}$ & 0 & .404 & .316 & 0.225 & $.848^{*}$ & .637 & $.794^{*}$ & 0.292 & $-.775^{*}$ & .447 & .690 & 0.277 & .316 & $.619^{*}$ & .500 & 0.181 & .520 & $-.759^{\prime}$ \\
\hline
\end{tabular}

Note: ${ }^{*},{ }^{* *}$ and ${ }^{* * *}$ indicate significant differences at $p<0.1, p<0.05$ and $p<0.01$ respectively. $r$ : Pearson 's correlation co-efficient; $p$ : $p$ value; DFL: Days to fifth leaf, SH: Seedling height, TD: Leaf temperature difference, LA: Leaf area, CNFL: Culm number at fifth leaf stage, DF: Days to flowering, PH: Plant height, CN: Culm number, CA: Culm angle, CD: Culm diameter, FLL: Flag leaf length, FLW: Flag leaf width, FLA: Flag leaf angle, FT: Number of fertile tillers/plant, FPL: First panicle length, NSP: Number of spikelets/1 ${ }^{\text {st }}$ panicle, NSB: Number of secondary branches, GL: Grain length, GW: Grain width 


\section{ACKNOWLEDGEMENT}

Authors acknowledge National Research Council, Sri Lanka for funding the research through NRC 12-129 grant and Plant Genetic Resources Centre, Sri Lanka for providing traditional rice seeds.

\section{REFERENCES}

Bambaradeniya, C. and Amerasinghe, P. (2004). Biodiversity associated with the rice field agro ecosystem in Asian countries: a brief review. http://books.google.com/books (Accessed on $03^{\text {rd }}$ June 2013).

Berger R. (2009). Participatory rice variety selection in Sri Lanka. Communitybased adaptation to climate change, pp. 88.

Chandraratna, M. F. (1964). Genetics and breeding of rice. Chapter 8: Flowering in rice with particular reference to photoperiod control. Lonmans, Green and Co Ltd, 48 Grosvenor Street, London, pp. 181 - 214

Dharmasena, P.B. (2010). Assessment of Traditional Rice Farming, A Case Study from Moneragala District of Sri Lanka, COMPAS Project Future In Our Hands Development Fund Badulla-2010, Indigenous Knowledge Practices Promotion Programme.

Endo-Higashi, N. and Izawa, T. (2011). Flowering Time Genes Heading date 1 and Early heading date 1, Together Control Panicle Development in Rice, Plant and Cell Physiology, 52 (6): 1083- 1094.

Food and Agriculture Organization of the United States. (2014). Rice Market Monitor, Volume XV1I (3).

International Rice Research Institute (IRRI), Rice Knowledge Bank. (2009). Best Management Practices for Low Land Irrigated and
Rainfed Rice. www.knowledgebank.irri.org.

Lin, Y. R., Wu, S. C., Chen, S. E., Tseng, T. H., Chen, C. S., Kuo, S. C., Wu, H. P. and Hsing, Y. C. (2010). Mapping of quantitative trait loci for plant height and heading date in two intersubspecific crosses of rice and comparison across Oryza genus. Botanical Studies, 52: 1-14.

Plant Genetic Resources Center [PGRC]. (2006). Characterization Catalogue on Rice (Oryza sativa) Germplasm, Department of Agriculture. Sri Lanka.

Rebeira, S. P., Wickramasinghe, H. A. M, Samarasinghe, W. L. G. and Prashantha, B. D. R. (2014). Diversity of Grain Quality Characteristics of Traditional Rice (Oryza sativa L.) Varieties in Sri Lanka. Tropical Agricultural Research, 25 (4): 570 - 578.

Team of NRC Research Project 12-129, (2014). Handbook on Varietal Diversity of Sri Lankan Traditional Rice Oryza sativa. ISBN 978-955-97102-4-0.

Wang, H., Pandey, S., Velarde, O. and Hardy B. (2012). Patterns of varietal adoption and economics of rice production in Asia. The International Rice Research Institute, Manila, Philippines.

Wei, X., Xu, J.,Guo, H., Jiang, L., Chen, S., Yu, C., Zhou, Z., Hu, P., Zhai, H. and Wan, J. (2010). DTH8 supresses flowering time in rice and influencing plant height and yield potential simultaneously. Plant Physiology, 153:1747-1758

Yano, M. (2001). Genetic and molecular dissection of naturally occurring variation. Current Opinion in Plant Biology, 4(2): 130-135.

Yoshida, S. (1983). Rice. In: Smith, W. H. 
(Editor) Proceedings of the symposium on potential productivity of field crops under different environments, The International Rice Research Institute. ISBN 971104114-6. 